\title{
Papp-Váry Árpád Ferenc \\ ORSZÁGMÁRKA-RANGSOROK A COVID-19 VILÁGJÁRVÁNY IDEJÉN - „AZ AZ EGY FONTOS: LEGYETEK JÓK MOST!”
}

\section{Absztrakt}

A termékek és szolgáltatások világában jó ideje megszokottak a márkarangsorok: a top100-as globális márkalistát többek közt elkészíti az Interbrand és a BrandZ-KantarWPP is. Az Interbrand 2020-as listájának első öt helyén például az Apple, az Amazon, a Microsoft, a Google és a Samsung áll, őket követi az első, nem technológiai márka, a CocaCola. De a BrandZ-Kantar-WPP 2020-as rangsora esetén is hasonló a helyzet, ott az első öt helyezett sorrendje: Amazon, Apple, Google, Microsoft, Visa.

A klasszikus márkarangsorokhoz hasonlóan az országmárkákra is rendelkezésre állnak már toplisták. Sőt, szinte minden évben megjelenik legalább egy új ilyen. Van már Anholt Nation Brands Index, FutureBrand Country Brand Index, Anholt Good Country Index, Bloom Consulting Country Brand Ranking (Tourism Edition, illetve Trade Edition), Young\&Rubicam Best Countries, Reputation Institute Country RepTrak és Global Soft Power Index is. Ezek mindegyikét lehetetlen taglalni egyetlen cikk keretei között, és nem is mindegyiknek van annyira friss országmárka-rangsora, ami már a Covid-19 járványidőszak alatt született, ezért most csak az első hármat vettük górcső alá közülük.

A publikáció egyik célja az, hogy magyar nyelven először bemutassa ezek módszertanát, dimenzióit és faktorait, illetve az egyes rangsorok eredményeit, különös tekintettel arra, hogy 2020-ban miként változtak. Az írás másik célja, hogy rámutasson arra, hogy a jó országmárka, a jó országimázs alapja voltaképp nem más, mint maga a jó ország, pontosan ugyanúgy, ahogy egy klasszikus márka esetében is a kiindulópont a jó termék és szolgáltatás.

Kulcsszavak: márkarangsorok; országmárka; országmárkázás

\section{Országok versenye a fejünkben}

Valljuk be, hajlamosak vagyunk országunkat más országokkal összehasonlítani. Vannak olyan nemzetek, melyek a képzeletbeli létrán alattunk vannak, és vannak, melyek felettünk. Lehet, hogy mindez összefügg a felsőbbrendűségi vagy éppen alsóbbrendűségi komplexusainkkal, de a marketing magyarázat is megtalálható mögötte. Az ugyanis, hogy hova teszünk egy országot, illetve országmárkát a létrán, lényegében attól függ, hogy milyen értékkel, értékekkel ruházzuk fel, milyen gondolataink, érzéseink támadnak az ország neve hallatán. Ahogy Kotler és Keller fogalmaznak (2006, pp. 370-371.), hogy: „A márka végül is olyasvalami, ami a fogyasztók elméjében létezik. (...) A márka ereje attól függ, hogy a vevő az idők során mit látott, olvasott, hallott, tudott meg, gondolt és érzett a márkával kapcsolatban. Más szóval a márka ereje a meglévő vagy potenciális vásárlók tudatában rejlik, és abban, hogy közvetve vagy közvetlenül milyen tapasztalataik voltak a márkával." 
Kérdés persze, hogy mindennek az értékét ki lehet-e számolni, tudományosan igazolni. Ez már klasszikus termékek, szolgáltatások esetében sem olyan egyszerű, de azért kísérletet tesznek rá az olyan márkarangsorok, mint az Interbrand Best Global Brands, vagy a BrandZ-Kantar-WPP The Most Valuable Global Brands.

Az országok esetében is időről-időre megjelenik egy-egy ilyen lista, melyeknek egy része vitatható, de vannak olyan rangsorok is, melyek az elmúlt években elfogadottá váltak, olyannyira hogy kormányok külügyminiszterei vagy akár miniszterelnökei vonnak le következtetéseket az eredmények alapján.

A listák közt vannak nem kifejezetten márkarangsorok, ám mégis érdemes kiemelni ezeket is gyakori idézettségük miatt. Ilyen az IMD Versenyképességi jelentés, illetve a World Economic Forum ország versenyképességi listája. Ahogy Bod Péter Ákos leszögezi a témával foglalkozó cikkében (2009, p. 32): „Ezeket szakmailag tekinthetjük szépségverseny-listáknak, amivel nem kell egyetérteni, és - mint a szépségversenyeken is gyakran az előkelő helyezés nem mindig tükröz valós értékeket, de azért a jelentős visszacsúszás egy ilyen listán ront az érintett ország külső megítélésén."

Rendszeresen állítanak hasonló rangsorokat olyan neves szaklapok is, mint a The Economist, a Forbes vagy a Euromoney. Egyfajta tematikus rangsornak nevezhetők a hitelminősítő intézetek országbesorolásai, mint a Moody's Investors Service, a Standard\&Poor's, a Fitch-IBCA vagy Japan Credit Rating Agency.

Jelen publikáció azonban a cikk témájához hűen nem ezekről, hanem kifejezetten az országmárka rangsorokról kíván szólni. Tudni kell, hogy szinte minden évben megjelenik legalább egy új ilyen, amit aztán évről-évre újra kiadnak. Van már Anholt Nation Brands Index, FutureBrand Country Brand Index, Anholt Good Country Index, Bloom Consulting Country Brand Ranking (Tourism Edition, illetve Trade Edition), Young\&Rubicam Best Countries, Reputation Institute Country RepTrak és Global Soft Power Index is. Ezek mindegyikét lehetetlen vállalkozás taglalni egyetlen cikk keretei között, és nem is mindegyiknek van annyira friss országmárka-rangsora, ami már a Covid-19 járványidőszak alatt született, ezért most csak az első hármat vesszük górcső alá közülük. A cikk az Anholt Nation Brands Index, a FutureBrand Country Brand Index, valamint az Anholt Good Country Index listák módszertanát, dimenzióit, faktorait mutatja be, majd elemzi a rangsorokban a Covid-19 világjárvány idején történt elmozdulásokat.

A részletes bemutatás előtt azonban érdemes még arról szólni, hogy mi is ezen rangsorok haszna. A nyilvánosan is elérhető rangsorok elöször is a közvélemény számára fontosak: mindenki számára érdekes lehet, hogy hol helyezkedik el a saját országa, vagy hogy miként állunk a szomszédainkhoz képest, illetve hogy mely országok megítélése a legjobb vagy éppen a legrosszabb a világban, különböző szempontok szerint. Nem véletlen, hogy a média is örömmel veszi az újabb és újabb rangsorokat és szívesen beszámol azokról, mert a téma biztosan érdeklődésre tart majd számot az olvasók, nézők, hallgatók részéről.

A rangsorok eredményei a más országokkal való összehasonlításon kívül még egy dologra jók: hogy az adott ország helyezése hogyan alakult a megelőző vagy éppen korábbi évekhez képest. Mivel az országimázs (vagy ha úgy tetszik országmárka) lassan változik, ezért ha jelentős elmozdulás történik az összesített listán vagy annak valamelyik dimenziójában, arra érdemes odafigyelni. 
Hogy egyes kormányzatok mennyire fontosnak tartják ezt, azt jól mutatja például Finnország évről-évre kiadott "Building the image of Finland Review of the country image" kiadványa. Ennek egyik kiemelt fejezete arról szól, hogy a különböző országmárka felmérések alapján hol helyezkedik el Finnország. Ezek alapján a dokumentumban megfogalmazzák az ország legfontosabb erősségeit és gyengeségeit, pontosabban hogy mit gondol azoknak a nemzetközi közvélemény, azaz miként látják a Finnország márkát (Finland.fi Toolbox, 2017).

A rangsoroknak azonban egy másik jelentősége is van: PR-értéket jelent a rangsor készítőinek, ezáltal fizetős kormányzati megbízásokat hozhat. Ez lehet egyrészt tanácsadás, de több rangsor eleve úgy készül, hogy a részletes országelemzések csak külön díjért érhetők el, fizetni kell értük a kutatás készítőinek. Skócia kormányzata például minden évben meg is teszi ezt az Anholt Nation Brands Index esetében, és aztán a részletes eredményeket publikálja is, ezáltal biztosítva, hogy az ott élők lássák, milyen az ország megítélése. Mindez abban is segít, hogy jobban alá tudja támasztani a kormányzat, különösen a külügyminisztérium, hogy ezek alapján milyen lépésekre van szükség, melyek tovább javíthatják az országot, és így az országmárkát (Scottish Government, 2021).

Végül, de nem utolsósorban, a rangsorok különösen fontosak lehetnek olyan helyzetben, amikor az egész világot érinti valami aktuális kérdés, jelen esetben a járvány. Az adott ország megítélésében való változás ilyenkor ugyanis akár arra is utalhat, hogy mennyire sikerült jól vagy éppen rosszul kezelni a járványt, pontosabban, hogy ez a kezelés hogyan jelent meg a nemzetközi médiában. Hiszen amikor egy országot megítélünk, abban rendkívül fontos szerepe lesz, hogy mik a legfontosabb információink az országgal kapcsolatban, milyen hírek jutottak el hozzánk róla, ha eljutottak.

A fentiek együtt talán jól összefoglalják azt, hogy ez egyes rangsoroknak milyen gyakorlati jelentősége és hasznossága van. Ha a rangsorok elemzését szisztematikusan teszi egy ország kormányzata, akkor mindenképpen jobban tisztában lesz azzal, hogy mit is gondol az országról a szélesen értelmezett nemzetközi közvélemény - legyen szó akár a járvány előtti, alatti, vagy utáni állapotról.

\section{Az Anholt Nation Brands Index}

Ez volt a legelső, az országokat mint márkákat rangsoroló kísérlet. A 2005-ben indult index, mely mára a világ egyik legnagyobb társadalomtudományi kutatásává nőtte ki magát, sokféle bonyolult néven futott már: először, mint Simon Anholt Nation Brands Index, majd később, mint Anholt-GMI Nation Brands Index, aztán 2008-tól, mint Anholt-GfK Roper Nation Brands Index, végül 2017-től mint Anholt Nation Brands Index powered by Ipsos.

Ahogy látható, ezekben a közös az Anholt szó, ami Simon Anholtra utal, aki az országmárka és országmárkázás fogalmak megteremtője, és egyben a terület leginkább ismert nemzetközi szaktekintélye, több könyve szerzője a témában.

A kutatás módszertana kapcsán fontos kiemelni, hogy az 20 országban méri reprezentatív mintán 50 ország befolyását és vonzerejét. Ez egyben a rangsort érő legtöbb kritika oka is: egyrészt csak 50 ország szerepel benne (bár például Magyarország igen), másrészt 
a felmérés maga csak 20 országban történik. Ahogy azonban szokták mondani, ha egy kutatás pontosan ugyanazt a hibát véti időről-időre, akkor az elmozdulások, a változások ugyanúgy értelmezhetőek lesznek, és itt most ez a lényeg. Ráadásul maga a minta viszonylag nagy, hiszen összesen 20.000 embert kérdeznek meg - és legutóbb 2020. július 7. és 30. közt tették azt, azaz amikor a Covid-19 világjárvány már jó négy hónapja kézzelfogható volt (Ipsos, 2020).

A mérés alapja hat dimenzió, ha úgy tetszik kompetenciacsoport (competence fields), összesen 23 faktor mentén. Ezeket foglalja össze az 1. táblázat.

1. táblázat: Az Anholt Nation Brands Index dimenziói és faktorai

\begin{tabular}{|l|l|}
\hline Dimenzió & Az adott dimenzióhoz tartozó egyes faktorok \\
\hline Turizmus & Utazás az országba abban az esetben, ha a pénz nem lenne szempont; \\
& Természeti szépség; \\
& Történelmi épületek; \\
& Lüktető́ hangulatú város \\
\hline Export & Tudomány és technológia; \\
& Termékek vásárlása; \\
& Kreatív hely \\
\hline Kormányzat & Hozzáértő és tisztességes; \\
& Jogok és méltányosság; \\
& Béke és biztonság; \\
& Környezet; \\
& Szegénység \\
\hline Letelepedés és befektetés & Munka és élet; \\
& Életminőség; \\
& Iskolai végzettségek; \\
& Üzleti befektetés; \\
& Társadalmi egyenlőség \\
\hline Kultúra & Sport; \\
& Kulturális örökség; \\
& Kortárs kultúra \\
\hline Emberek & Örömmel lát; \\
& Közeli barát; \\
& Foglalkoztathatóság \\
\hline
\end{tabular}

Forrás: Papp-Váry, 2019

E szempontrendszer és az arra épülő felmérés eredményei alapján a legjobb országmárka 2020-ban ismét Németországé volt, ami immár hatodik éve végez sorozatban az élen. A top 10-ben többségben vannak az európai országok (Németország, Egyesült Királyság, Franciaország, Olaszország, Svájc, Svédország), de Kanada, Japán, Ausztrália és az Egyesült Államok is bekerült. Igaz, utóbbi korábban még volt, hogy az 1. helyen végzett, most pedig már csak a 10., ami azt mutatja, hogy a globális közvélemény (vagy legalábbis a felmért 20 ország megkérdezettjei) körében romlik az USA megítélése (Ipsos, 2020).

Utóbbi kapcsán érdekes lehet, hogy ha az egyes dimenziókat vizsgáljuk (ld. a 2. táblázatot), az Egyesült Államok a legjobban az export és a kultúra kategóriában szerepel. Előbbiben nincs semmi különösebb meglepetés, hiszen a globális márkák nagy többsége amerikai, legyen szó akár technológiai cégekről, akár élelmiszerekről, gyorsétterem-láncokról, akár pénzügyi szolgáltatókról, és még sorolhatnánk a szektorokat. A kultúra területén az USA 50 ország közül megszerzett 5 . helye viszont talán elsőre túlzottan is előkelőnek tűnhet. De ha tudjuk, hogy ide nemcsak a kulturális örökség tartozik (amire az országnak, 
lévén, hogy 1776-ban alapították, korlátozott lehetőségei vannak), hanem a modern kultúra is, beleértve a filmeket vagy éppen a popzenét, sőt ebbe a pontba értendő a sport is, akkor máris érthető az eredmény.

A 2. táblázat még egy érdekességre rámutat: ha arra keressük a választ, hogy melyik lehetne a legideálisabb országmárka, akkor az nem más, mint Olaszország és Németország kombinációja. Az egyik ország ugyanis épp abban erősebb, amiben a másik gyenge, és fordítva. Míg Olaszország turizmusát és kultúráját igen magasra értékelik, ahogy az itt élő embereket is, addig a letelepedés és befektetés dimenzió már lényegesen alacsonyabb pontszámokat kap, a kormányzásról nem is beszélve. Ezzel szemben Németországban az emberek, a tájak, a kultúra, az ételek vagy éppen a divat gyengébb, míg általában erősre értékelt a kormányzás, a gazdaság, valamint a „mérnöki” brandek. Így voltaképp, ha egyesítenék Olaszországot és Németországot, akkor a világ legjobb országa, vagy legalábbis legjobb országmárkája jöhetne létre. Persze ha felidézzük, hogy a 20. században erre voltak törekvések, akkor gyorsan rájövünk, hogy ez mégsem annyira jó ötlet.

2. táblázat: A top5 ország az Anholt Nation Brands Index összesített rangsorában és 6 dimenziójában

\begin{tabular}{|l|l|l|l|l|l|l|l|}
\hline Helyezés & $\begin{array}{l}\text { Összesített } \\
\text { rangsor }\end{array}$ & Turizmus & Export & Kormányzat & $\begin{array}{l}\text { Letelepedés } \\
\text { és } \\
\text { befektetés }\end{array}$ & Kultúra & Emberek \\
\hline $\mathbf{1}$ & Németország & Olaszország & Japán & Kanada & Kanada & Olaszország & Kanada \\
\hline $\mathbf{2}$ & $\begin{array}{l}\text { Egyesült Ki- } \\
\text { rályság }\end{array}$ & Franciaország & $\begin{array}{l}\text { Amerikai } \\
\text { Egyesült Ál- } \\
\text { lamok }\end{array}$ & Svájc & Németország & Franciaország & Ausztrália \\
\hline $\mathbf{3}$ & Kanada & $\begin{array}{l}\text { Egyesült Ki- } \\
\text { rályság }\end{array}$ & Németország & Svédország & Svájc & $\begin{array}{l}\text { Egyesült Ki- } \\
\text { rályság }\end{array}$ & Olaszország \\
\hline $\mathbf{4}$ & Japán & Spanyolország & $\begin{array}{l}\text { Egyesült Ki- } \\
\text { rályság }\end{array}$ & Németország & $\begin{array}{l}\text { Egyesült Ki- } \\
\text { rályság }\end{array}$ & Németország & $\begin{array}{l}\text { Egyesült Ki- } \\
\text { rályság }\end{array}$ \\
\hline $\mathbf{5}$ & Franciaország & Görögország & Kanada & Ausztrália & Svédország & $\begin{array}{l}\text { Egyesült Ki- } \\
\text { rályság }\end{array}$ & Ausztrália \\
\hline
\end{tabular}

Forrás: Ipsos, 2020

\section{A FutureBrand Country Brand Index}

Az Anholt Nation Brands Index után a második legismertebb rangsor a FutureBrand tanácsadó céghez kötődik, mely 75 országot értékel - azokat, melyek a Világbank adatai alapján a top75-be tartoznak GDP-jük (bruttó hazai termék) szerint. Az értékelés alá vont dimenziók a 3. táblázatban láthatók. 
3. táblázat: A FutureBrand Country Brand Index dimenziói és faktorai

\begin{tabular}{|c|c|}
\hline Dimenzió & Az adott dimenzióhoz tartozó egyes faktorok \\
\hline Értékrend & $\begin{array}{l}\text { Politikai szabadság; } \\
\text { Környezettudatosság; } \\
\text { Tolerancia }\end{array}$ \\
\hline Életminőség & $\begin{array}{l}\text { Oktatás; } \\
\text { Éászségügy; } \\
\text { Életszínvonal; } \\
\text { Biztonság; } \\
\text { Az ottani élet/tanulás vonzereje }\end{array}$ \\
\hline Üzleti potenciál & $\begin{array}{l}\text { Jó infrastruktúra; } \\
\text { Fejlett technológiák; } \\
\text { Jó üzleti környezet }\end{array}$ \\
\hline Turizmus & $\begin{array}{l}\text { Ár-érték arány; } \\
\text { Látnivalók; } \\
\text { Az emberek vágya arra, hogy ide utazzanak szabadságra; } \\
\text { Üdülőhelyek/Szálláshelyek; } \\
\text { Gasztronómia }\end{array}$ \\
\hline Örökség és kultúra & $\begin{array}{l}\text { Örökség; } \\
\text { Történelmi érdekességek; } \\
\text { Művészet és kultúra; } \\
\text { Természeti szépség } \\
\end{array}$ \\
\hline Made in (származási hely) & $\begin{array}{l}\text { Hiteles/autentikus termékek } \\
\text { Minőségi termékek } \\
\text { Egyedülálló termékek } \\
\text { Az emberek vágya arra, hogy itt készült termékeket vegyenek }\end{array}$ \\
\hline
\end{tabular}

Forrás: FutureBrand, 2020

Míg az első három asszociáció (értékrend, életminőség, üzleti potenciál) az ország úgymond státusát határozza meg, addig a másik három (turizmus, örökség és kultúra, származási hely) az (ország)élményt. Mindezek alapján mind a hat dimenzióra külön rangsor állítható fel, illetve azok alapján egy összesített lista is készíthető.

Utóbbi szerint, azaz a Future Brand Index 2020-as össz toplistáján az élen Japán áll, őt Svájc, Norvégia, Németország, Kanada, Dánia, Finnország, Svédország, az Egyesült Arab Emírségek, végül Új-Zéland követi. Érdemes itt kiemelni a skandináv országok dominanciáját, hiszen mind a 4 bekerült a top10-be.

Érdekesség még, hogy Magyarország a 75 ország közül az 56. helyen végzett, ami jelentős visszaesés, mert a 2019-es rangsorban még a 38. helyen állt.

A kutatás adatfelvétele 2020. szeptember 2. és 11. között történt, amikor jó féléve tombolt a Covid-19 világjárvány. Így a felmérésbe bevont szakértőket erről is kérdezték, azaz, hogy szerintük mely országok kezelték legjobban a járványt. A vélemények alapján az állampolgárok szerint jellemzően az alábbi tevékenységek, intézkedések járultak hozzá az adott országok kríziskezeléséhez:

- Gyors cselekvés

- Megelőző intézkedések megtétele

- Világos és alkalmazható útmutatások

- Következetes irányelvek

- Szigorú szabályok és előírások

- Lezárt országhatárok 
- Felszerelések biztosítása

- Nemzeti egység/összefogás

- Mindenki felelőssége

- Pénzügyi támogatások

- Nyugodt, józan megközelítés

Nos, a 2000 megkérdezett szakértő 2020 szeptemberi véleménye alapján ezek az országok kezelték (a felmérés időpontjáig) legjobban a járványt: Thaiföld, Tajvan, Japán, USA, Svédország, Dél-Korea, Németország, Kína és Új-Zéland. A Future Brand riportja azt is kiemelte, hogy a Covid-19 járvány időszakában az országmárkák még fontosabbak, mint valaha - mert bár nem kontrollálhatunk eseményeket, de azt igen, hogy azoknak menynyire ellenálló az ország.

A Future Brand részben ennek kapcsán azt is összegyűjtötte, hogy mikor látnak sikeresnek egy országot kívülről, és mikor nem. Ezt foglalja össze a 4. táblázat.

4. táblázat: Amitől egy országot sikeresnek látnak, és amitől sikertelennek

\begin{tabular}{|l|l|}
\hline $\begin{array}{l}\text { Ha egy országot sikeresnek látnak } \\
\text { országmárkaként, az alábbiak jellemzik: }\end{array}$ & $\begin{array}{l}\text { Ha egy országot sikertelennek látnak } \\
\text { országmárkaként, az alábbiak jellemzik: }\end{array}$ \\
\hline Magabiztos & Megbízhatatlan \\
Befolyásos & Nem szavahihető \\
Politikailag stabil & Gyenge \\
Gazdaságilag progresszív & Elavult \\
Innovatív & Korrupt \\
Megbízható & Gazdaságilag és politikailag instabil \\
Tiszteletet keltő & Nem biztonságos \\
Toleráns & Agresszív \\
Szavahihető & Rossz az üzleti környezet \\
Biztonságos & Lassú \\
Őszinte & Barátságtalan/intoleráns és tiszteletlen \\
Jól fejlett & \\
Vezető szerepet játszik & \\
Jó az üzleti környezet & \\
Független & \\
Hiteles és jó életminőségű & \\
\hline
\end{tabular}

Forrás: FutureBrand, 2020

\section{Az Anholt Good Country Index}

A FutureBrand nevéhez köthető táblázat már részben mutatja azt is, hogy a jó országmárka a jó országon múlik - akárcsak a klasszikus termék esetében, ahol a kiindulópont a jó termék és szolgáltatás.

Nem véletlen, hogy a téma első számú nemzetközi szaktekintélye, Simon Anholt 2014ben előállt egy új toplistával, mely az országokat már nem az alapján rangsorolja, hogy mennyire vonzók és milyen a márkaimázsuk, hanem hogy mennyi jót tesznek a világért. Ez egy nagy filozófiai váltás volt, Anholt ugyanis a 2000-es évek elejétől kezdve közel tizenöt éven át a márkaimázs fontosságáról beszélt és írt: országmárka hatszög modellje szerint, amikor megítélünk országokat, akkor hat dimenzió alapján gondolunk rájuk, ezek a turizmus, az export, a kormányzás, a letelepedés-befektetés, a kultúra és az emberek. Ezekről kell tehát minél jobb képet kifelé sugároznia, ami persze összefügg azzal is, hogy az egyes területeken mit tesz, azaz hogy mi a valóság, amire az imázs épül. 
Az egyes országok a fenti hat dimenzióban értékelt imázsa, valamint összimázsa alapján született meg a korábban ismertetett Anholt Nation Brands Index még 2005-ben, ami hosszú-hosszú éveken át meghatározó lett az országmárka-építés, mint tevékenység értékelésekor.

Igaz, az országmárkázás szót már ekkor is igyekezett Anholt kerülni, helyette a versenyképes identitás (competitive identity) kifejezést használta (Anholt, 2007). Egyben rámutatott arra is, hogy az országmárka kampányok sok esetben mennyire hatástalanok. „Mióta elkezdtem dolgozni ezen a területen, nem láttam egy fikarcnyi bizonyítékot, egyetlen megfelelően alátámasztott tanulmányt sem, amely bebizonyította volna, hogy a marketingkommunikációs programok, szlogenek, vagy logók bármikor is sikeresen megváltoztatták volna, illetve megváltoztathatnák a különböző helyek nemzetközi percepcióját." (Anholt, 2009) „Azok a kormányok, amelyek az adófizetők pénzét arra költik, hogy a világ színe előtt hangoztassák, mennyire menő, fantasztikus, csodálatos, vonzó az ország, nemhogy nem méltók a hatalomra, de börtönbe kellene kerülniük, mert ez a tevékenység értelmetlen.” - írta (Anholt, 2016, p. 134). Vagy éppen: „Nevetséges a nation branding eszméje: fogj egy országot, és változtasd fogyasztói termékké!” (Anholt, 2016, p. 133).

Mint azt markánsan leszögezte: „Nem hiszek e módszer létezésében, de ha mégis létezik, biztosan nincs semmi köze a kommunikációhoz, a logóhoz vagy a szlogenekhez, legfeljebb a kormányzati intézkedésekhez." (Anholt, 2016, p. 134.) Ezen a vonalon elindulva egyre inkább azt próbálta megfejteni, melyek lehetnek a jó kormányzati intézkedések, és melyek a rosszak - nem elsősorban az adott ország, hanem a világ szempontjából.

Azok a problémák, amiket meg kell oldania az egyes nemzeteknek, valójában ugyanis mind globális problémák: a klímaváltozás, a migráció, a terrorizmus, a mélyszegénység, az egyenlőtlenség, a háborús konfliktusok és az emberi jogok érvényesülése. Ezen felül Anholt még egy szempontot kiemelt 2014-ben, amikor az első ezzel foglalkozó nagy beszédét tartotta: a pandémiát, és a biológiai biztonságot. Már akkor is hangsúlyozta, hogy ezt a világméretű problémát is csak közösen tudják kezelni az országok, nem oldható meg befelé forduló gondolkodással. Amire tehát szükség van, az „Több összefogás, több együttműködés, és egy kicsit kevesebb verseny”. (TEDx Amsterdam, 2014)

Anholt legfrissebb, 2020-ban megjelenő könyve ezért egyenesen azt a címet kapta: „The Good Country Equation: How We Can Repair the World in One Generation” (A jó ország egyenlet: Hogyan javíthatjuk meg a világot egyetlen generáció alatt). Mint ebből is kiderül, nem elég az országoknak szépnek lenniük, az is fontos, hogy jók legyenek.

Némileg vicces, hogy jó pár évvel ezt megelőzően ugyanerre jutott egy brit humorista, Danny Wallace, akit legtöbben az „Igenember” („Yes Man”) című könyv, illetve film kapcsán ismerhetnek, mely az ő tollából született. Wallace 2005-ben egy hatrészes dokumentarista komédiát készített a BBC-nek, ahol azt járta körül, hogyan alapítsuk meg a saját országunkat („How to start your own country?”). Ennek során rengeteget kutatott, különböző EU-s hivatalnokokkal, vagy éppen minállamok vezetőivel interjúzott, végül aztán a saját lakásán megalapította az országát, amelynek zászlót terveztetett, felénekelte a himnuszát, és állampolgárokat toborzott. Az ország nevét pedig egy több ezer főt vonzó londoni rendezvényen jelentette be: ez az ország lett a „Lovely”. Témánk szempontjából 
azonban ennél is fontosabb, hogy az ország alkotmányát mindössze két szóban összegezte: „Be good”, azaz „Légy jó”.

Nos, ha Anholt valamiért nem is ismerte Wallace „How to start your own country” sorozatát, voltaképp a Good Country Index is a „Be good” elvből kiindulva született meg: azt mutatja meg, hogy az egyes országok mit tesznek meg a saját erejükből másokért, a globális közösség jólétéért.

„A Good Country Index ötlete meglehetősen egyszerű: mérjük meg, hogy a Föld országai mivel járulnak hozzá a közjóhoz az emberiség szintjén, és mit vesznek el abból. Ehhez felhasználjuk az ENSZ és más nemzetközi szervezetek adatainak széles körét, és minden ország esetében mérleget vonunk, hogy rögtön látható legyen: az adott ország az emberiség nettó hitelezője, vagy épp fordítva, azaz teher a bolygó számára, vagy valahol a kettő között áll." - fogalmazta meg a program lényegét Simon Anholt 2014-es TED-előadásában, melyet azóta közel ötmillióan láttak a Youtube-on (TEDx Amsterdam, 2014).

A Good Country Indexben tehát nincs országimázs dimenzió, és nincs közvéleménykutatás se az egyes országok imázsának felmérésére, mint a szintén Anholthoz köthető Nation Brands Index esetében. Helyette „kemény számok” vannak: 35 olyan adatpont összetett statisztikája, amelyek jó részét az ENSZ biztosítja - igaz, azt azért érdemes hozzátenni, hogy amikor az adott évi Good Country Index megjelenik, az ahhoz használt, rendelkezésre álló statisztikák valójában már jó pár évesek. A 35 adatpont 7 kategóriára bontható, melyet az 5. számú táblázat mutat.

Míg a jóország-index 2019-es rangsora még 153 országot vizsgált, addig a 2020-as már csak 149-et, mert ennyiről állt rendelkezésre megfelelő mennyiségű, nyilvánosan elérhető adat. Az eredmények alapján itt is sorrendbe állíthatók a nemzetek az egyes kategóriákban, valamint kihirdethető az abszolút győztes is.

Anholt ugyanakkor már az erről szóló, 2014-es TED-es előadásában is hangsúlyozta, hogy nem a jó (good), jobb (better) és legjobb (best) országokról van szó, hanem inkább úgy lehetne fogalmazni, hogy ez a good, gooder és goodest lista. Még fontosabb, hogy a rossz, rosszabb, legrosszabb ország értelmezést is célszerű elkerülni: ezek az országok nem rosszak, hanem inkább önzők. Saját magukra figyelnek, és nem érdekli őket a világ sorsa. 
5. táblázat: A jóország-index (Good Country Index 1.4 változat) hét dimenziója

\begin{tabular}{|c|c|}
\hline Kategória & Elemei (GDP arányosan értelmezve) \\
\hline Tudomány és technológia & $\begin{array}{l}\text { Az országban tanuló külföldi hallgatók száma } \\
\text { Tudományos folyóiratok és szaklapok exportja } \\
\text { Megjelent nemzetközi publikációk száma } \\
\text { A Nobel-díjak száma (halmozott érték) } \\
\text { Szabadalmak száma }\end{array}$ \\
\hline Kultúra & $\begin{array}{l}\text { Kreatív termékek exportja } \\
\text { Kreatív szolgáltatások exportja } \\
\text { UNESCO hátralékos tartozások (negatív mutató) } \\
\text { A személyek szabad mozgása, pl. kiutazási vízumkorlátozások } \\
\text { Sajtószabadság (A Riporterek határok nélkül és a Freedom House in- } \\
\text { dexe alapján; negatív mutató) }\end{array}$ \\
\hline $\begin{array}{l}\text { Nemzetközi } \quad \text { béke } \quad \text { és } \\
\text { biztonság }\end{array}$ & $\begin{array}{l}\text { A kiküldött ENSZ békefenntartó katonák száma } \\
\text { Hátralékos tartozások az ENSZ békefenntartás költségvetésében } \\
\text { (negatív mutató) } \\
\text { Nemzetközi erőszakos konfliktusok: a nemzetközi szervezett bűnözés } \\
\text { áldozatainak száma (negatív mutató) } \\
\text { A fegyver- és lőszerexport szintje (negatív mutató) } \\
\text { Internetes biztonság: Globális Kiberbiztonsági Index mutató }\end{array}$ \\
\hline Világrend & $\begin{array}{l}\text { Jótékonysági adakozásban résztvevők aránya } \\
\text { A befogadott menekültek száma } \\
\text { A külföldön tartózkodó menekültek száma (negatív mutató) } \\
\text { Születési ráta; a születések aránya a népességben (negatív mutató) } \\
\text { Az aláírt ENSZ egyezmények száma }\end{array}$ \\
\hline Bolygó- és klímapolitika & $\begin{array}{l}\text { Nemzeti Ökológiai Lábnyom (negatív mutató) } \\
\text { Megfelelőség a környezetvédelmi megállapodások terén } \\
\text { A veszélyes növényvédőszerek exportja (negatív mutató) } \\
\text { Megújuló energia aránya a teljes energiafogyasztásban } \\
\text { Ózon: az ózonréteget lebontó anyagok fogyasztása (negatív mutató) }\end{array}$ \\
\hline Prosperitás és egyenlőség & $\begin{array}{l}\text { Nyitott kereskedelem: A határokon átnyúló kereskedelem helyzete } \\
\text { ENSZ-önkéntesek külföldön } \\
\text { Pénzátutalások költsége (negatív mutató) } \\
\text { Közvetlen külföldi befektetések (FDI-kiáramlás) } \\
\begin{array}{l}\text { Fejlesztési segítségnyújtás: Hozzájárulások a fejlesztési } \\
\text { együttmüködések terén }\end{array}\end{array}$ \\
\hline Egészség és jóllét & $\begin{array}{l}\text { Élelmiszer-segélyezés } \\
\text { Gyógyszeripari export } \\
\text { Önkéntes többletadományok a WHO részére } \\
\text { Humanitárius segélyadományok } \\
\text { Megfelelőség a Nemzetközi Egészségügyi Rendszabályok terén }\end{array}$ \\
\hline
\end{tabular}

Forrás: The Good Country Index, n.d.

Na de melyik a legjobb (pontosabban a goodest, azaz a legönzetlenebb) ország a legfrissebb, 2020-as rangsor alapján? Nos, ez nem más, mint Svédország, amely úgy végzett az összesített lista első helyén, hogy külön-külön egyik kategóriában sem került az élre, viszont kiegyensúlyozottan jó teljesítményt nyújtott: 5 kategóriában szerepel az első 10ben a 149 ország közül, és ha a statisztikáit nézzük, lényegében mind a hét felsorolt dimenzióban az emberiség nettó hitelezője, azaz több jót tesz a bolygóért, mint rosszat.

Ami szembetűnő még, hogy az összesített rangsor első 10 helyezettje egy kivételével mind európai. A top 10-be sorrendben Svédország, Dánia, Németország, Kanada, Hollandia, Finnország, Franciaország, az Egyesült Királyság, Spanyolország és Norvégia került. Mindez Anholt szerint amiatt van, mert ezek az országok valóban sokat (sok jót) tesznek más országokért, különösen persze Európán belül, illetve ha tagjai, akkor az Európai 
Unión belül. Ahogy azt Anholt minden beszédében kiemeli, valójában az egyik legfantasztikusabb dolog a jobb világ megteremtéséért maga az Európai Unió.

De mi a helyzet, ha az egyes kategóriák dobogósait vizsgáljuk? A 6. táblázatra tekintve rögtön láthatunk néhány érdekességet. Az egyik ilyen az lehet, hogy a világrendért a legtöbb pozitív dolgot (legalábbis az ENSZ adatok és ezen rangsor szerint) az az ország teszi, amelyik sok-sok évtizede kirobbantotta a világháborút. Sőt, Németország még egy dimenzióban az élre került, ez az egészség és jólét. Ennél is érdekesebb lehet, hogy két kategóriában is Georgia (korábbi nevén Grúzia) áll az élen: a nemzetközi béke és biztonság tekintetében, illetve a prosperitás és egyenlőség viszonylatában ők tesznek a legtöbbet a világért - ezen eredmény könnyebben érthető, ha tudjuk, hogy az adatokat minden esetben súlyozzák az ország GDP-jével, ami Georgia esetében nem túl magas.

A legérdekesebb azonban nekünk magyaroknak a tudomány kategória lehet, ahol Magyarország a 2. helyen végzett. Mindez annak köszönhető, hogy (megint csak a GDP-hez viszonyítva) jól teljesítünk a külföldi diákok vonzásában, a nemzetközi publikációkban, valamint a Nobel-díjasok számában - ez a rangsor ugyanis nemcsak azt is figyelembe veszi, hogy hol élt, dolgozott az adott Nobel-díjas, amikor megkapta a díjat, hanem azt is, hogy hol született.

6. táblázat: A top 10 ország az Good Country Index összesített rangsorában és 7 dimenziójában

\begin{tabular}{|c|c|c|c|c|c|c|c|c|}
\hline Helyezés & $\begin{array}{l}\text { Összesített } \\
\text { rangsor }\end{array}$ & $\begin{array}{l}\text { Tudomány } \\
\text { és } \\
\text { technológia }\end{array}$ & Kultúra & $\begin{array}{l}\text { Nemzetközi } \\
\text { béke és } \\
\text { biztonság }\end{array}$ & Világrend & $\begin{array}{l}\text { Bolygó- és } \\
\text { klíma- } \\
\text { politika }\end{array}$ & $\begin{array}{l}\text { Prosperitás } \\
\text { és } \\
\text { egyenlőség }\end{array}$ & $\begin{array}{l}\text { Egészség } \\
\text { és } \\
\text { jóllét }\end{array}$ \\
\hline 1 & Svédország & Ukrajna & Belgium & Georgia & $\begin{array}{l}\text { Németor- } \\
\text { Szág }\end{array}$ & Norvégia & Georgia & $\begin{array}{l}\text { Németor- } \\
\text { Szág }\end{array}$ \\
\hline 2 & Dánia & $\begin{array}{l}\text { Magyaror- } \\
\text { szág }\end{array}$ & Hollandia & Írország & Ausztria & Finnország & Dánia & Norvégia \\
\hline 3 & $\begin{array}{l}\text { Németor- } \\
\text { szág }\end{array}$ & $\begin{array}{l}\text { Egyesült Ki- } \\
\text { rályság }\end{array}$ & Luxemburg & Mongólia & Hollandia & Svájc & Dél-Korea & Svédország \\
\hline 4 & Kanada & Csehország & Dánia & $\begin{array}{l}\text { Kirgizisz- } \\
\text { tán }\end{array}$ & Ausztrália & Svédország & Szingapúr & Dánia \\
\hline 5 & Hollandia & Lettország & Svédország & Ruanda & Finnország & Litvánia & Luxemburg & Hollandia \\
\hline 6 & Finnország & Ausztria & Ausztria & Uruguay & Norvégia & $\begin{array}{l}\text { Horvátor- } \\
\text { szág }\end{array}$ & $\begin{array}{l}\text { Egyesült } \\
\text { Arab Emi- } \\
\text { rátusok }\end{array}$ & Svájc \\
\hline 7 & $\begin{array}{l}\text { Franciaor- } \\
\text { szág }\end{array}$ & Dánia & $\begin{array}{l}\text { Franciaor- } \\
\text { szág }\end{array}$ & Moldova & Dánia & Szlovénia & Ciprus & $\begin{array}{l}\text { Egyesült Ki- } \\
\text { rályság }\end{array}$ \\
\hline 8 & $\begin{array}{l}\text { Egyesült Ki- } \\
\text { rályság }\end{array}$ & $\begin{array}{l}\text { Bosznia- } \\
\text { Hercego- } \\
\text { vina }\end{array}$ & Szlovénia & Bulgária & Málta & $\begin{array}{l}\text { Németor- } \\
\text { szág }\end{array}$ & Botswana & Kanada \\
\hline 9 & $\begin{array}{l}\text { Spanyolor- } \\
\text { szág }\end{array}$ & Hollandia & Észtország & Szingapúr & Svédország & Portugália & Svédország & $\begin{array}{l}\text { Amerikai } \\
\text { Egyesült Ál- } \\
\text { lamok }\end{array}$ \\
\hline 10 & Norvégia & Finnország & Málta & Malawi & Ciprus & Ausztrália & Mauritius & $\begin{array}{l}\text { Egyesült } \\
\text { Arab Emi- } \\
\text { rátusok }\end{array}$ \\
\hline
\end{tabular}

Forrás: The Good Country Index, n.d.

Ha Magyarország összesített eredményét nézzük, a 30. helyen állunk a 149 ország közt az Anholt Good Country Indexben, ami előrelépés a korábbi évhez képes, amikor 39.-ek voltunk, igaz, 153 országból. Ami kevésbé jó hír, hogy szinte mindegyik európai ország megelőzi hazánkat, de itt a tanulmány végén nézzük a rangsor jó (good) oldalát: Magyarország mögött lemaradva állnak az olyan világhatalmak, mint az Amerikai Egyesült Államok (38.), Oroszország (47.) vagy Kína (60.). 


\section{A három országmárka rangsor és eredményeik összehasonlítása}

Miként a fentiekben olvasható volt, a három országmárka mérési módszertan meglehetősen eltérő, még úgy is, hogy abból kettő mögött Simon Anholt áll. Ami leginkább hasonlít, az a dimenziók száma és az ezekhez kapcsolódó faktorok száma. Nagy különbség van azonban a vizsgált országok száma közt (50 - 75 - 149), nem is beszélve a minta nagyságáról: míg az Anholt Nation Brands Index esetében 20.000 ember véleményét kérik ki, addig a The Future Brand Country Index esetében ugyanez 2.000 fő, igaz, az egy szakértői minta, az Anholt Good Country Index esetében pedig közvéleménykutatás helyett nyilvános ENSZ-adatok alapján rangsorolnak. Ezt mutatja a 7. táblázat.

7. táblázat: A három országmárka rangsor összehasonlító elemzése

\begin{tabular}{|c|c|c|c|}
\hline $\begin{array}{l}\text { Összehasonlítási } \\
\text { szempont }\end{array}$ & $\begin{array}{l}\text { Anholt Nation Brands } \\
\text { Index }\end{array}$ & $\begin{array}{l}\text { The Future Brand } \\
\text { Country Index }\end{array}$ & $\begin{array}{l}\text { Anholt Good Country } \\
\text { Index }\end{array}$ \\
\hline $\begin{array}{l}\text { Az első ilyen rangsor } \\
\text { megjelenésének éve }\end{array}$ & 2005 & 2010 & 2014 \\
\hline Dimenziók száma & 6 & 6 & 7 \\
\hline Faktorok száma & 23 & 22 & 35 \\
\hline $\begin{array}{l}\text { Értékelt országok } \\
\text { száma }\end{array}$ & 50 & $\begin{array}{l}75 \text { (a Világbank top75 } \\
\text { GDP alapján) }\end{array}$ & 149 \\
\hline Mintavétel & $\begin{array}{l}\text { Összesen } 20.000 \text { ember, } \\
\text { de csak } 20 \text { országból, } \\
\text { akik mindegyike véle- } \\
\text { ményt mond az } 50 \text { or- } \\
\text { szágról }\end{array}$ & $\begin{array}{l}\text { Összesen } 2.000 \text { szak- } \\
\text { értő, véleményvezér, } \\
\text { akik gyakran utaznak, } \\
\text { mindegyikük 7-7, szá- } \\
\text { mára közel álló országot } \\
\text { értékel }\end{array}$ & $\begin{array}{l}\text { Nem közvélemény-ku- } \\
\text { tatással történik, hanem } \\
\text { ENSZ tényadatok alap- } \\
\text { ján, azokat GDP arányo- } \\
\text { san értelmezve }\end{array}$ \\
\hline $\begin{array}{l}\text { Utolsó } \quad \text { adatfelvétel } \\
\text { ideje }\end{array}$ & $\begin{array}{l}2020 . \text { július } 7 \text {. és au- } \\
\text { gusztus } 30 . \text { közt ( } 4 \text { hó- } \\
\text { napja tartott a Covid-jár- } \\
\text { vány) }\end{array}$ & $\begin{array}{l}\text { 2020. szeptember } 2 \text {. és } \\
\text { 11. közt ( } 6 \text { hónapja tar- } \\
\text { tott a Covid-járvány) }\end{array}$ & $\begin{array}{l}\text { Az ENSZ-adatok rendel- } \\
\text { kezésre állása lassabb, } \\
\text { mindig pár évvel ezelőt- } \\
\text { tiek. (A Covid-hatás eb- } \\
\text { ben a rangsorban még } \\
\text { nem érzékelheto.) }\end{array}$ \\
\hline
\end{tabular}

Forrás: Saját összehasonlítás az egyes rangsorok alapján, 2021

Bár ez egyes módszertanok közt aránylag nagy a különbség, azok végeredményeit tekintve, különösen a top10 országokat vizsgálva, már nem annyira. Ahogy a 8. táblázatból látható mindhárom rangsor élbolyában ott van Németország, Kanada és Svédország. Kétszer került be a top10-be hét ország is: Dánia, az Egyesült Királyság, Finnország, Franciaország, Japán, Norvégia és Svájc. Persze vannak olyan országok is, melyek csak egy rangsorban szerepelnek ennyire elől: az Amerikai Egyesült Államok, Ausztrália, Hollandia, Olaszország, Spanyolország és Új-Zéland. Ilyen tekintetben tehát ismét csak megerősítést nyert, hogy a jó országmárka alapja a jó ország. 
8. táblázat: A top10 ország a három országmárka rangsorban

\begin{tabular}{|l|l|l|l|}
\hline Helyezés & $\begin{array}{l}\text { Anholt Nation Brands } \\
\text { Index }\end{array}$ & $\begin{array}{l}\text { The Future Brand } \\
\text { Country Index }\end{array}$ & $\begin{array}{l}\text { Anholt Good Country } \\
\text { Index }\end{array}$ \\
\hline $\mathbf{1}$ & Németország & Japán & Svédország \\
\hline $\mathbf{2}$ & Egyesült Királyság & Svájc & Dánia \\
\hline $\mathbf{3}$ & Kanada & Norvégia & Németország \\
\hline $\mathbf{4}$ & Japán & Németország & Kanada \\
\hline $\mathbf{5}$ & Franciaország & Kanada & Hollandia \\
\hline $\mathbf{6}$ & Olaszország & Dánia & Finnország \\
\hline $\mathbf{7}$ & Svájc & Finnország & Franciaország \\
\hline $\mathbf{8}$ & Ausztrália & Svédország & Egyesült Királyság \\
\hline $\mathbf{9}$ & Svédország & Egyesült Arab Emírségek & Spanyolország \\
\hline $\mathbf{1 0}$ & Amerikai Egyesült Államok & Új-Zéland & Norvégia \\
\hline
\end{tabular}

Forrás: Saját összehasonlítás az egyes rangsorok alapján, 2021

\section{„Az az egy fontos: legyetek jók most!”}

Elsőre furcsán hangozhat, hogy a Napoleon Boulevard együttes dalszövege az országmárkaépítés során az egyik legfontosabb tanács, de mint tanulmányban bemutatott jóország-index (Good Country Index) is bizonyította, nagyon is így van. Sőt, ha megkeressük a szöveg eredetijét, érdekes összefüggést fedezhetünk fel. Valójában ugyanis egy olasz mozi zenéjéről van szó: a „State bouni se potete” („Legyetek jók, ha tudtok!”) 1984-ben jelent meg, bár Magyarországon csak 1989-ben mutatták be. A filmben az egyik gyereket (majd később felnőttet) folyamatosan megkísérti az ördög, miközben pártfogója, Néri (Szent) Fülöp próbálja jó útra terelni - ahogy azt a 16. században a valóságban is tette az utcagyerekekkel és a bűnözőkkel. Néri (Szent) Fülöp fö üzenete valójában nemcsak az, hogy „Legyetek jók, ha tudtok!”, hanem miként az eredeti olasz cím még fordítható, és ahogy a filmben utalnak rá: „Maradjatok jók, ha tudtok!”

Nos, ha valamikor különösen fontos ez a tanács, akkor most, a Covid-19 világjárvány időszakában újra így van. Ha jobban belegondolunk, a második világháború óta az első igazán közös ügy, ami mindenki napi életére hatással van, szerte az egész bolygón. Persze lehetne mondani akár a klímaváltozást is, ám amiatt nem kell maszkot hordani, vagy éppen bezárkózni otthon és nem találkozni senkivel. Legalábbis egyelőre nem.

Ez egyben azt is jelenti, hogy a Földön élő közel nyolcmilliárd embernek van egy közös élménye (reméljük, nemsokára már csak emléke): a koronavírus. Mindez akár lehetőséget is adna a globális összefogásra, egymás segítésére, de ha őszinték vagyunk, ennek legfeljebb csíráit látjuk. Helyette a politikusok elsősorban a saját országaikkal foglalkoznak, saját állampolgáraik felé fordulva kommunikálnak. A fő üzenetük az, hogy megvédik az adott országot, nem pedig az, hogy összefognak a többi országgal és együtt legyőzik a vírust. A határellenőrzések visszaállítása vagy éppen megerősítése is a nemzetek bezárkózását mutatja, a többi ország piros, sárga vagy jó esetben zöld színű jelölésével. A vakcinafejlesztésben is verseny van, nem csak a cégek, de az országok között is: sok helyen folyik a kutatás, ám csak részben osztanak meg egymással információkat. Eközben azt is látjuk, hogy a gazdag országok előre lekötöttek többmillió vagy akár többtízmillió vakcinát, miközben a szegényebb országok ezt nem tehetik meg. Minderre még külön kifejezés is született: vakcina nacionalizmus. Igaz, már most is van rá példa, hogy bizonyos fejlett 
országok felajánlják a segítségüket, de összességében a fentiek inkább kiélezik a különbségeket. Mindez pedig a többi globális kihívás megoldására is hatással van: Bill Gates szerint a mélyszegénység felszámolásában a pandémia egyenesen huszonöt évvel ezelőtti szintre vetette vissza a világot (Business Insider, 2020).

Ugyanakkor mindez nem varrható pusztán a politikusok nyakába, sőt! Éppenséggel a közvéleménykutatások szinte mindenütt azt mutatják, hogy az emberek most erre voltak vevők: az a jó vezető, aki a sajátjainak tudja a legtöbbet nyújtani, az a jó ország, amelyik önző módon magára gondol. Ez pedig egyben azt is jelenti, hogy Anholt és csapata előtt még sok munka áll a jóország szemlélet elfogadtatása terén, azaz hogy az országok önzetlenebbek legyenek, és ne csak és ne elsősorban magukat helyezzék a középpontba, hanem az egész világ sorsát.

\section{Irodalomjegyzék}

Anholt, S. (2007). Competitive Identity - The New Brand Management for Nations, Cities and Regions. Palgrave MacMillan.

Anholt, S. (2009. január 16.): Why Nation Branding Does Not Exist. https://kommunikationsmaaling.dk/artikel/why-nation-branding-does-not-exist/

Anholt, S. (2016). A nagy országmárka svindli. HUG - Hungarian Geopolitics Magazine, 1(1), 132-149. https://issuu.com/pageo/docs/hug_online_marcius_boritoval_

Anholt, S. (2020). The Good Country Equation: How We Can Repair the World in One Generation. BerrettKoehler Publishers.

Bod, P. Á. (2009). Magyarország tőkepiaci megítélése - Okok és következmények. Marketing és Menedzsment, 43(2), 30-37.

BrandZ - Kantar - WPP (2020). Top 100 Most Valuable Global Brands 2020. https://www.kantar.com/campaigns/brandz/global

Business Insider (2020. szeptember 15.). Bill Gates says the pandemic wiped out 25 years of vaccine progress in 25 weeks https://www.businessinsider.com/bill-gates-pandemic-wiped-out-25-years-progress-vaccines-2020-9

Finland.fi Toolbox (2017. április 24.). Building the image of Finland - review of the country image work 20152016 (Finland.fi, Toolbox, Research and Strategy. https://toolbox.finland.fi/strategy-research/buildingimage-finland-review-country-image-work-2015-2016/

FutureBrand (2020. november). The FutureBrand Country Brand Index 2020 - A unique country perception study. https://www.futurebrand.com/futurebrand-country-index-2020

Interbrand (2020). Best Global Brands. https://interbrand.com/best-global-brands/

Ipsos (2020. október 27.). Germany Retains Top "Nation Brand" Ranking, the UK and Canada Round Out the Top Three. https://www.ipsos.com/en-ca/news-polls/Germany-Retains-Top-Nation-Brand-Ranking-theUnited-Kingdom-emerges-ahead-of-Canada-to-Round-Out-the-Top-Three-US-and-China-Experience-Significant-Decline

Kotler, P. \& Keller, K. L. (2012). Marketingmenedzsment. Akadémiai Kiadó.

Papp-Váry, Á. (2019). Országmárkázás - Versenyképes identitás és imázs teremtése. Akadémiai Kiadó.

Scottish Government (2021. február 23.). The Anholt-Ipsos Nation Brands IndexSM: 2020 Report for Scotland. https://www.gov.scot/publications/anholt-ipsos-nation-brands-indexsm-2020-report-scotland/

TEDX Amsterdam (2014. december 1.). Good country party / Simon Anholt [Video]. YouTube. https://www.youtube.com/watch?v=ndJw3tdOR8g

The Good Country Index (n.d.): About. Version 1.4. https://index.goodcountry.org/ (Letöltés dátuma: 2021. április 2.)

Wallace, D. (2005). How to start your own country? Episode 1-6. BBC Television Documentary Comedy Series, BBC. 